\title{
The making of a littoral minzu: The Dan in late Qing-Republican intellectual writings
}

\author{
Gary Chi-hung Luk \\ The Chinese University of Hong Kong, Hong Kong \\ Author for correspondence: Gary Chi-hung Luk, E-mail: garyluk@cuhk.edu.hk
}

(Received 18 May 2021; accepted 21 July 2021)

\begin{abstract}
Tracing the assumption behind China's nationality identification that the Dan constituted a littoral minzu, this article examines the rise and circulation of "Dan" as a racial entity in writings by Chinese thinkers, reformers, and scholars in the first half of the twentieth century. It explains how "Dan" emerged as a $z u$, minzu, zhongzu, and renzhong in late-Qing political polemics and pedagogical texts, and how this notion was combined with Republican-era scholarship on the Dan within and across the disciplines of popular literature, folklore, ethnohistory, and anthropology. Both Western and imperial Chinese scholarly trends and racialist ideas shaped pre-1949 Dan studies. Modern intellectuals presented the Dan as a non-Han minority based on various nationalist concerns as well as their Han and regional identities. From a historical perspective, this article redraws the geoethnic landscape of modern China by taking transregional littoral fringes into consideration and calling for attention to those identified as non-Han before the nationality investigation in the 1950s but as Han afterward.
\end{abstract}

Key words: Dan; ethnicity; ethnohistory; folklore; nationality; race

\section{Introduction}

In his 1729 edict permitting the "Dan households" (Danhu 蛋戶) to settle ashore and register in the same way as the ordinary people, the Yongzheng 雍正 emperor described the Dan as a "mean household” (jianji 賤藉) and its members as boat dwelling-fishing pariahs spreading over Guangdong. ${ }^{1}$ More than two centuries later, the authorities of the new People's Republic of China (PRC) in Guangdong and Fujian conducted extensive surveys in the two provinces in 1952-1953 on various communities of the Dan as a shaoshu minzu 少數民族 (minority nationality), a prelude to the countrywide “nationality identification" (minzu shibie 民族識別). ${ }^{2}$ Although the Dan were eventually classified as Han 漢 rather than a shaoshu minzu in 1955, the nationality inquiry itself indicates the popular perception or hypothesis that the Dan constituted a minzu 民族 in the first years of the PRC. How did the Dan transform from late imperial outcasts on watery margins to a non-Han minzu on the eve of the nationality identification campaign in mid-twentieth-century China?

To answer this question, this article explores the rise and circulation of the notion of “Dan" 蛋/蛋 as a racial category in writings by Chinese thinkers, reformers, and scholars in China from the last years of the Qing (1636-1912) to the Republican period (1912-1949). Much scholarship has examined the roles of Nationalist and Communist authorities as well as Chinese and foreign scholars in defining,

\footnotetext{
${ }^{1}$ Zhan 2009, pp. 117-18.

${ }^{2}$ Fan 2012, pp. 934-37; Huang 2016, pp. 151-52; Zhan 2004. On the nationality identification, see Huang 1995; Mullaney 2011.

(c) The Author(s), 2021. Published by Cambridge University Press. This is an Open Access article, distributed under the terms of the Creative Commons Attribution-NonCommercial licence (http://creativecommons.org/licenses/by-nc/4.0), which permits non-commercial re-use, distribution, and reproduction in any medium, provided the original article is properly cited. The written permission of Cambridge University Press must be obtained prior to any commercial use.
} 
reifying, and redrawing the racial and ethnic boundaries between the Han and non-Han in the twentieth century. ${ }^{3}$ By highlighting the modern Chinese intellectual efforts to construct the Dan as a non-Han minzu, this article refashions the geoethnic landscape of twentieth-century China. As an imagined translocal minority, the Dan were geographically unique, widely conceived to inhabit different localities on the edges of coasts and waterways, either in rural areas or within or adjacent to towns and cities in Guangdong, Fujian, and (rather sparsely) Guangxi. The case of the Dan, thus, challenges the existing rural-urban dichotomy and regional-intercardinal divisions (i.e. the Southwest versus the Southeast) in most ethnic studies of China on the one hand, and to incorporate littoral fringes into the country's geoethnic topography on the other. Moreover, Guangdong and Guangxi were commonly regarded as part of China's Southwest (Xi'nan 西南) and the Dan as a minzu therein for much of the twentieth-century period. ${ }^{4}$ This article thus enhances the ethnic diversity of the Southwest by integrating watery margins into its ethnic landscape.

Similar to the PRC period, nationalist thoughts and academic trends were both pivotal to the making of the ethnic landscape of China prior to 1949. Different from Yunnan province, where most of the people known to be non-Han before 1949 were recognized as shaoshu minzu in the PRC's nationality identification, the littoral fringes across China were home to the Dan and some other groups identified as non-Han before 1949 but categorized as Han in the 1950s. ${ }^{5}$ In fact, like the participants in the 1950s nationality identification, many writers of the Dan prior to the campaign acknowledged that the Dan shared many attributes with and had been largely assimilated into the Han. They still treated the Dan as a non-Han minzu largely due to their racialist ideas inherited from the imperial Chinese past and imported from the West, and their desire to construct China as a multi-minzu state with the Han as the majority and basis.

Rather than a social history of the Dan people's interactions with other ethnic groups, on which there has been enormous scholarship, ${ }^{6}$ this article is the first English-language study on the modern intellectual history of the Dan as a $z u$ 族, zhongzu 種族, minzu, and renzhong 人種. ${ }^{7}$ Dan studies emerged and developed as a subject of inquiries largely thanks to the introduction, from the West and Japan, of racial theories and social Darwinian evolutionary ideas as well as other academic fields and social scientific approaches. Yet, at the same time, the twentieth-century intellectuals who discussed the Dan as a $z u$, zhongzu, or minzu were in varying degrees influenced by the imperial literati's descriptions and racialist perceptions of the Dan and other minority groups. Many of them also inherited late-imperial scholarly traditions such as categorizing the Yi 夷 and distinguishing them from the Chinese, interests in folksongs, and the evidential (kaozheng 考證) approach and philology. The case of the Dan thus exemplifies the coexistence and confluence of the "imported" and "indigenous" scholarly trends in the intellectual development of twentieth-century China.

Not only modern Western and imperial Chinese thoughts, the writers were also driven by various nationalist feelings and concerns as well as a regional-ethnic identity to portray and study the Dan. Late-Qing reformist and revolutionary intellectuals presented the Dan in their polemical writings and local teaching materials that reconfigured the relationship between the Han and non-Han as an attempt to construct a new national identity during the transition of China to a nation-state. ${ }^{8}$ In the Republican period, amateur and professional scholars studied the Dan out of the desire to develop a new form of Chinese literature and national culture, to strengthen China by solving its "national

\footnotetext{
${ }^{3}$ Gladney 1991, pp. 65-115; Harrell 1995; Huang 2018; Leibold 2007; Mullaney 2011.

${ }^{4}$ Wang 2018, p. 8.

${ }^{5}$ One example is the Jiuxing yuhu 九姓漁戶 (“Nine-surname fishing households”) in Zhejiang. See Tong 1931 ; Sato 2016.

${ }^{6}$ One representative study is Siu and Liu 2006.

${ }^{7}$ Chinese-language reviews of Republican-era studies on the Dan are all too brief. For example, see Huang 2008. Traceable to imperial Chinese records, mixed with imported racial theories, and complicated by modern social scientific disciplines, $z u$, minzu, zhongzu, and renzhong were terms used by late Qing-Republican authorities and scholars to refer to various peoples and open to interpretation. To maintain their original meanings and avoid semantic anachronism, this article leaves $z u$, minzu, zhongzu, renzhong, and associated terms in pinyin.

${ }^{8}$ On this transition, see Harrison 2001; Leibold 2007, pp. 17-47; Zarrow 2012.
} 
problems" (minzu wenti 民族問題) in line with the Nationalist principles, and, in the 1930s and 1940s, to mobilize and unite the myriad of minority groups under the banner of "Zhonghua minzu” 中華民族 against the Japanese aggression. ${ }^{9}$ Despite their diverse nationalist orientations, the major modern writers of the Dan under purview self-identified as Han in Guangdong or Fujian. ${ }^{10}$ This article illustrates the inseparability of the authors' nationalist, ethnic, and regional dispositions in scholarship on minzu in modern China.

This article comprises three main sections. The first section explains how the Dan, a late-imperial household category, a long-held discriminative exonym, and a subject of traditional Chinese racialist discourse, emerged as a distinctive racial group in late-Qing political polemics and pedagogical texts. The second and third sections shows how scholars of Republican China - particularly Zhong Jingwen 鍾敬文 and Luo Xianglin 羅香林 - incorporated the idea of Dan as a $z u, m i n z u$, and/or renzhong into their studies on the Dan's folksongs, lives and customs, history, and physique within and across the fields of popular literature, folklore, ethnohistory, and anthropology. ${ }^{11}$ The conclusion summarizes the late Qing-Republican intellectual representations of the Dan and how they informed the social surveys and nationality inquiries of the Dan in the early years of the PRC as well as contemporary Dan scholarship. It also briefly explains why the Dan, identified for so long as a non-Han $z u$ or minzu, was finally classified as Han during the nationality identification in the 1950s.

\section{The Dan in the late-Qing racial discourse}

Dan 廹 first appeared in Chinese texts as a denomination for non-Han people in the fourth century. In the Song period (960-1279), officials and literati began to use the word to refer specifically to southern water-dwellers. In late imperial times, "Dan" constituted an ethnonym in literati writings, an official household category, and a discriminative status marker (or what anthropologists call an "ethnic marker") in local society. The literati portrayed the Dan as poor boat-dwelling or shed-living outcasts in Fujian and Guangdong who eked a living on littoral fringes and maintained distinct marriage and religious customs. They often admired the Dan's fondness for singing and recorded their folksongs, and their lives and customs were frequent themes of poems circulating in Guangdong. During the Ming and early Qing, the state authorities made "Dan" a distinct type of household encompassing those living on littoral fringes in Guangdong. Before Emperor Yongzheng's emancipation order, the Dan householders were barred from marrying land dwellers, settling ashore, and taking the civil service examination. After the emancipation, many remained to be identified by the state as the Dan and their lowly socioeconomic status persisted. At a social level, territorial-based groups in Fujian and Guangdong imposed the prejudiced label of "Dan" on their watery-margin neighbors to differentiate between "us" and "them" and reject the latter's settlement rights on land. ${ }^{12}$

Emma Jinhua Teng has identified the "ethnical discourse" on indigenes in late imperial China that centers on cultural differences while emphasizing human universals. The late-imperial conception of the Dan, however, was predicated on their widely perceived subhuman origins and traits, physical distinctions, and geocultural attributes. This "racialist discourse" or "embryonic form" of "racial consciousness" predated the introduction of modern racial theories into China. ${ }^{13}$ The Dan were classified in the literati writings as a tribe $(z u)$ or “stock" of people (zhong 種) either untraceable or descendant from the Yi or Fan 番 in the south. Like the other Yi and Fan, the Dan were animalized. The Dan's

\footnotetext{
${ }^{9}$ On the "national problem" and how nationalist concerns informed minority studies, see Huang 2018; Leibold 2007; Wang 2013.

${ }^{10}$ On the Han identity, see Mullaney, Leibold, Gros, and Bussche 2012.

${ }^{11}$ Rather than a comprehensive review of Dan scholarship, this article excludes some Republican-era historians of the Dan such as Chen Xujing 陳序經 as well as the early sociological surveys on the Dan, which assumed that the Dan constituted essentially “Han-ized” (Hanhua) “waterborne residents” (shuishang jumin 水上居民) of the Republic rather than a non-Han minority.

${ }^{12}$ Siu and Liu 2006; Faure 2007, pp. 41-44; Szonyi 2002, pp. 42-47; Zhan 2009.

${ }^{13}$ Dikötter 2015, p. 2; Teng 2004.
} 
genesis was mythologized and associated with legends about sea animals and snake, and the epithets used to describe them included fish, dragon, otter, clam, and shrimp. Also like other Yi, the physical characteristics of the Dan were highlighted. Their ancestors were thought to have tattooed bodies and cut hair, and the Fujian people labeled the Dan boat dwellers with purportedly deformed leg muscles as "crooked foot" (quti 曲蹄). ${ }^{14}$ Geographical determinism also informed popular images of the Dan. It was assumed that they lived on water and thus tended to be stupid, and that their waterborne residence induced violence and piracy. ${ }^{15}$

First introduced into China by foreign missionaries, Western racial ideas translated from the European and Japanese languages transformed the textual representations of the Dan in the last decade of the Qing. Alarmed by foreign imperialist threats, Han intellectuals advocating reforms or revolution at the turn of the twentieth century mixed foreign "scientific" racial-evolutionary thoughts with the "indigenous" discourse of clans, lineage, and tribal groups in their political polemics for national strength and survival. As part of nation-building efforts, they refashioned China's position in the world and the relations between the Han majority and non-Han minorities within China on a new, racially based discursive terrain. ${ }^{16}$ Zhong and $z u$ were used interchangeably with zhongzu to classify and depict peoples of different skin colors across the globe (such as the primitive Black and the advanced Yellow, to the latter "race" China's people belonged) as well as peoples within China. A borrowed term from Japan, zhongzu semantically combined zhong and $z u$, classifiers since ancient times meaning clans bound by blood ties, lineages claiming the same descent, or tribes inhabiting the same territory. A less frequent term is minzu, which denoted kinship groups in late-imperial records but was employed as a Japanese loan term by some late-Qing writers to refer to the whole or part of the constituents of a nation-state. ${ }^{17}$ Since the late 1890 s, $z u$, zhong, minzu, and zhongzu in intellectual writings served to draw and harden the racial, historical, and/or cultural boundaries between different groups within China on the one hand, and to highlight their internal biological-descendant linkage on the other. In addition to the Han, Manchus, Mongols, Hui 回, and Tibetans, those groups included the southern natives such as the Miao 苗, Yao 猺, and, pertinent to this study, Dan.

Among the prominent late-Qing intellectuals who included the Dan in their discursive paradigms was Liu Shipei 劉師培, a prolific writer of anti-Manchu revolutionism. In 1903, Liu published A Book of Expulsion (Rangshu 攘書). As the book title indicates, Liu, inheriting the imperial tradition, emphasized the difference between the "Chinese" ( $\mathrm{Hua}$ 華) and the Yi and clamored for expelling the Yi - the Manchus being one - from the history of China and the future nation-state that should only include the Chinese or Han. Influenced by the environmental-biological determinism of Wang Fuzhi 王夫之, a Han chauvinist in the seventeenth century, Liu began the chapter on "Yi species" (yizhong 夷種) with the assertion that the harsh climate of the Yi's habitats resulted in their diametrically distinct customs, physical appearance, and innate disposition. Like imperial-era historians, he linked ancient animal-associated ethnonyms to the non-Han of his time at different corners of China. He quoted the second-century dictionary Shuowen jiezi 說文解字 (Explanation of Single-component Graphs and Composite Characters) to trace the nonhuman descent of six species of the Yi offspring, classifying the Dan - with reptile (cong 虫) as the character's radical - as southern Yi. Inheriting the Qing evidential scholarship, Liu traced the tribal continuity of the Dan as a southern Man 蠻 $z u$ from a Jin-dynasty (266-420) gazetteer and other classical Chinese texts. Liu then quoted foreign evolutionary writings such as Charles Darwin's to argue that the Dan and other Yi were at an early stage of human development. ${ }^{18}$ For Liu, the Dan constituted a primitive southern Yi who owed their nonhuman origins to their living environment and whose evolution as a $z u$ had a long history, both of

\footnotetext{
${ }^{14}$ Hao 1792 [1730], p. 42; Szonyi 2002, p. 45.

${ }^{15} \mathrm{Qu} 1985$ [1700], vol. 2, pp. 485-86.

${ }^{16}$ Leibold 2007, pp. 17-47.

${ }^{17}$ Dikötter 2015, p. 19; Huang 2018, pp. 69-97; Zarrow 2006.

${ }^{18}$ Liu 1934-1936 [1903], pp. 3-5; Schneider 2017, pp. 209-69; Yang 1999a, pp. 111-82.
} 
which explained their unassimilability into the Han. In short, Liu's discourse on the Dan was informed by both the traditional Chinese and Western racialist discourses and scholarly trends.

Liang Qichao 梁啟超, the preeminent reform-minded intellectual, pioneered to examine the Dan and other non-Han in China's past and present within the framework of minzu. As a political journalist he published "Observation on China's Historical Minzu" ("Lishishang Zhongguo minzu zhi guancha” 歷史上中國民族之觀察; hereafter “Historical Minzu”) in 1905. The treatise explained the historical development of eight minzu in China with the aim to "arouse the common sentiment of our minzu," that is, the "Zhonghua minzu." Inventing this far-reaching term, now typically translated as "the Chinese nation," Liang regarded the Zhonghua minzu as identical to the Hanzu 漢族. Han-centric and upholding "greater nationalism" (da minzu zhuyi 大民族主義), Liang envisioned that the Han would become the ethnocultural core of a strong multi-minzu state. Rather than Liu Shipei's exclusionary thoughts, Liang subscribed to inclusionist culturalism and believed in the Han's assimilative power. Virtually all the minzu within China, Liang argued, had been integrated into the Zhonghua minzu. ${ }^{19}$

The Dan, however, were one of the few exceptions to Liang's narrative of the non-Han's historicalcultural assimilation into the Han. In "Historical Minzu," he attached his discussion on the Danzu 蛋 族 to the section on the southern Baiyuezu 百粤族. Liang was intrigued that the Dan, more than a million, still lived on watercraft. While tracing their ancient origins from the classical texts also cited by Liu Shipei, Liang, speaking as a native of Guangdong, had no idea of where the local Dan originated and when they migrated from land to water. Identifying himself as Han, Liang asserted that the persecution of “our $z u$ " (wozu 我族) resulted in the Dan's escape to water and evasion of conflicts with the land-dwelling Han as well as their survival for several thousand years, their zhong having been preserved as remnants of the Baiyuezu. With traditional geographical determinism in mind, Liang contended that the Dan's waterborne residence determined their present unassimilable status as a residual minzu. On the other hand, in a tone informed by Western racial ideas, Liang emphasized their "pure blood" (chuncui de xuetong 純粹的血統) as material in academic studies on the ancient Baiyuezu. ${ }^{20}$ Like the case of Liu Shipei, both imperial Chinese and Western racialist thoughts informed Liang's discourse on the Dan.

Liang Qichao was a nationally famous intellectual. At a local level, the Dan were also presented within a modern racial paradigm in the native-place (xiangtu 鄉土) gazetteers and textbooks, pedagogical texts compiled by the regional literati and educated elite in the first decade of the twentieth century. Used in primary school lessons on local history and geography under the new-style education system during the late Qing's New Policy period (1901-1911), the xiangtu teaching materials served to cultivate among the students a sense of locality (loving one's native place) as the basis of their patriotism and national identity (loving the state). To connect native-place and national education, the gazetteer and textbook compilers employed various strategies to refashion the locality that fit into the envisioned nation-state. One of these strategies was to classify and describe the local groups of people - Han or non-Han, indigenous or late-coming - under new racial categories such as zhongzu and "humans" (renlei 人類). ${ }^{21}$ In Guangdong and Fujian, these people included the Dan. For example, in the 1906 native-place gazetteer of Houguan 侯官, a riverine Fujian county, under the renlei section is an entry on the Danzu suggesting that the Dan in Fujian and Guangdong belonged to the same human species. ${ }^{22}$

Though influenced by imported racial ideas, the late Qing native-place teaching materials were not new in terms of genre, aim, and the description of the Dan. Traditional gazetteers ( $z h i$ 志) had a long history of describing tribes as $z u$ or zhong, categorizing them, and incorporating them textually into the empire or "core" of China. The compilers of the late-imperial gazetteers and late-Qing xiangtu

\footnotetext{
${ }^{19}$ Huang 2018, pp. 82-92; Schneider 2017, pp. 67-142; Zarrow 2006; Zarrow 2012, pp. 150-59.

${ }^{20}$ Liang 1905

${ }^{21}$ Ching 2007; Zarrow 2015.

${ }^{22}$ Zhu and Zheng 2001 [1906], pp. 383-84.
} 
gazetteers both narrated the locality and its linkage to the state in their own versions. ${ }^{23}$ Apart from racial knowledge, the native-place gazetteer and textbook writers also incorporated entries of imperial gazetteers and literati writings into their portrayals of the Dan. Appropriating the legendary account of the Dan by the early Qing literatus Qu Dajun 屈大均 in New Comments on Guangdong (Guangdong $x i n y u$ 廣東新語), the passage on the types of Guangdong people in a 1906 history textbook depicted the Dan as one of the various $z u$ descending from the Yue 越 people who rebelled against Qin rule (221-206 BCE) and took refuge on water. ${ }^{24}$ Nonetheless, as gatekeepers who disseminated the political-social ideas espoused by the government and national-level intellectuals, the late-Qing xiangtu gazetteer and textbook authors promoted the idea that the Dan were a zhong or zhongzu in the reconstituted local history and human geography. ${ }^{25}$ By 1949, descriptions of the Dan as a non-Han $z u$ often appeared in school textbooks under the zhongzu or minzu category. ${ }^{26}$

To conclude, in their efforts to transform China into a nation-state and forge a new national identity, Chinese thinkers and educated elite represented China's peoples within new discursive paradigms during the Qing's last years. Influenced by both imported racial-evolutionary beliefs and imperial Chinese literati thoughts and scholarly approaches, they classified the Dan as a $z u$, zhongzu and minzu and discussed the extent of their assimilability into the Han or Chinese, with whom the intellectuals all self-identified. Though marginal in the whole late-Qing racial discourse, which mostly concerned the Han and Manchus, the intellectual portrayals of the Dan transformed "Dan" from a late-imperial household type and a discriminatory exonym entangled in traditional Chinese racialist discourse into a newly constructed racial entity based on both the Chinese and Western scholarly thoughts. The late-Qing perception of the Dan as a $z u$, minzu, or zhongzu informed much later scholarship.

Liang Qichao's "Historical Minzu," in particular, heralded twentieth-century studies on the Dan in a number of ways. His national prominence and the preeminence of his New Citizen Journal (Xinmin congbao 新民叢報), where “Historical Minzu" was first published, suggest the dissemination of his novel notion that the Dan constituted a minzu during his time and beyond. He pioneered tracing the Dan's minzu status to their origins and relations with the Han, both central themes in later ethnohistorical studies on the Dan. Methodologically, Liang's (and also Liu Shipei's) evidential approach to the Dan history resonated down the twentieth century. Liang's call for attention to the blood of the Dan as a residual minzu, moreover, predated the racially informed anthropological approach in Republican China. Last but not least, Liang's regional (Guangdong) identity prompted him to discuss the Dan in "Historical Minzu." As shown below, Republican-era scholars of the Dan were mainly natives of either Guangdong and Fujian, where the Dan were supposed to concentrate.

\section{New literature and folklore}

In modern China, academic attention to the Dan as a minzu originated from the new literature (xin wenxue 新文學) campaign. An outgrowth of the May Fourth-New Culture Movement, the campaign subverted what criticized as the Confucianism-dominated, classical Chinese literature and promoted popular or folk literature (minjian/pingmin wenxue 民間/平民文學) as the basis of vernacular literature and a new national culture. To promote folk literature, many intellectuals clamored for "going to the people" and collecting their orally transmitted folksongs, folktales, and the like. Much attention was paid to ballads and other folk literature and art of the non-Han minorities across the country, who, the promoters assumed, enjoyed thriving literature and "uncontaminated" cultures thanks to their remoteness to the Confucian-dominated center. ${ }^{27}$

\footnotetext{
${ }^{23}$ Dennis 2015; Hostetler 2001.

${ }^{24}$ Huang 2015 [1906], p. 189.

${ }^{25}$ Ching 2007, p. 57.

${ }^{26}$ Culp 2007, p. 68.

${ }^{27}$ Chow 1960; Hung 1985.
} 
Zhong Jingwen's scholarship on folksongs circulating in Guangdong was integral to the folk literature movement in Republican China. The movement began when a group of faculty and students at Peking University, or Beida 北大 for short, initiated a countrywide collection of folksongs in $1918 .^{28}$ Zhong Jingwen was the first and keenest one in Guangdong devoted to this folksong campaign. A youth in his native county of Haifeng 海豐 in eastern Guangdong, Zhong actively participated in the local anti-Japanese student activities during the May Fourth Movement, which, as he recalled, awakened his patriotism and passion for new culture and new literature. Inspired by Folksong Weekly (Geyao zhoukan 歌謠週刊), Beida's national platform for folk literature, Zhong submitted to the journal the folksongs he gathered in Haifeng and published there in 1924-1925 a series of short articles on the local folk literature. ${ }^{29}$

Zhong pioneered collecting and examining the songs chanted by the Dan people in the twentieth century. He started gathering Dan folksongs in 1924 and published eight of them in $1926 .{ }^{30}$ In 1927 he published "A Glimpse of the Dan-people Literature in China" ("Zhongguo Danmin wenxue yiluan” 中 國蛋民文學一戀; hereafter “Dan-people Literature”), an essay on the "saltwater songs” (xianshuige 鹹水歌) of the Dan. The same year saw his publication of Dan Folksongs (Dan ge 蛋歌), the first ever academic monograph on the Dan. Its main contents comprise a revision of "Dan-people Literature" and fifty-two Dan folksongs assembled and transcribed by Zhong between 1924 and $1927 .{ }^{31}$

Why was Zhong Jingwen interested in Dan folksongs? He was driven by a "romantic May Fourth vision" whereby folk literature reflected the minds of country folk including non-Han minorities. ${ }^{32}$ In "Dan-people Literature," Zhong incorporated the idea of minzu into his theories on the relations between folksongs, literature, and civilization. For Zhong, folksongs of a minzu constituted their literature representing their voices from the heart (xinsheng 心聲). From an evolutionary-dichotomous perspective Zhong contended that in contrast to the relatively civilized minzu such as the Han, the collective voices of the "uncivilized" (wei kaihua 未開化) minzu across China were stronger than their individual voices. He then applied these theories to the Dan, regarding them as a boat-dwelling uncivilized minzu and their saltwater songs as collective "voices from the heart of the Dan minzu" (Danjia minzu de xinsheng 蛋家民族的心聲). Zhong was the first scholar who elevated the songs of these uneducated non-Han people into "very valuable literature" (jiyou jiazhi de wenxue 極有價 值的文學). ${ }^{33}$

Zhong's motivation for gathering and studying Dan folksongs demonstrates the Han intellectual endeavors on preserving the oral literature of non-Han minzu as part of the folk literature movement and a basis of rejuvenating Chinese national culture. Through identifying Dan saltwater songs as folk literature, Zhong drew a line that divided him, a "civilized" Han, and the Dan, an "uncivilized" non-Han minzu. In "Dan-people Literature," Zhong argued that to intensify the folksong campaign, it was necessary for "us, the Han" (women Hanren 我們漢人) to excavate the limitless treasure of folksongs from the mouths of the Dan and other uncivilized minzu such as those living in mountain. ${ }^{34} \mathrm{He}$ paid attention to folksongs of other minorities such as the Yao. ${ }^{35}$ In his later years, Zhong highlighted the importance of the folksong campaign, to which his collection of non-Han minorities' songs belonged, in the construction of a new Chinese culture during the May-Fourth era. His interest in minzu folksongs exemplifies the ideal of the popular literature proponents who bore the "Han man's burden" to preserve the culture of the "primitive" non-Han people, which, long suppressed by the "aristocratic culture" (guizu wenxue 貴族文學), would contribute to a reinvigorated national culture. ${ }^{36}$

\footnotetext{
${ }^{28}$ Hung 1985, pp. 32-57.

${ }^{29}$ Yang 1999b, pp. 17-87; Zhong 1997, pp. 3-5, 53-54, 238-43.

${ }^{30}$ Zhong 1926a; Zhong 1927a, p. 15.

${ }^{31}$ Zhong 1927a; Zhong 1927c.

${ }^{32}$ Hung 1985, p. 75.

${ }^{33}$ Zhong 1926b, p. 230; Zhong 1927c.

${ }^{34}$ Zhong $1927 \mathrm{c}$.

${ }^{35}$ Zhong 1928.

${ }^{36}$ Leibold 2007, pp. 147-76; Zhong 1998 [1989].
} 
Zhong's fascination with Dan folksongs as the collectively composed literature of a minzu originated in his imagination of their living world. He believed that uncivilized minzu with simple socioeconomic lives enjoyed blossoming singing customs and constituted different "countries of singers" (gezhe zhi guo 歌者之國). For him the Dan were one of these minzu whose "romantic and poetically beautiful" (langman er shimei 浪漫而詩美) environment on water induced the birth of the saltwater songs as a kind of precious Chinese literature. ${ }^{37}$ Yet, though attracted by their singing, Zhong seldom went to the Dan literally for their folksongs. His lyrics in Dan Folksongs were transcribed from the songs sung from memory by his friend who roamed around coastal central Guangdong, those recorded from the mouth of a co-worker at a primary school in Haifeng, and those obtained from another friend in a written form. An amateur folksong enthusiast, Zhong never questioned the authenticity of these indirectly collected pieces. ${ }^{38}$ Zhong's work on the Dan's folksongs was thus based not on fieldwork but on his idealization of their floating and singing lives, which resembles both the contemporary intellectuals' romanticization of the folk and the late-imperial literati's fascination with lives on water and the Dan's singing customs.

Zhong noted that many saltwater songs were indecent. He attributed their vulgarity and obscenity to the primitive lives of the Dan and their concomitant lack of linguistic training and plain way of expression. Notwithstanding this deficiency, Zhong appreciated that the Dan expressed their feelings directly and naturally in their folksongs, mostly centered on love. The following is a saltwater song, presumably chanted by a male, that Zhong quoted to explain its unadorned expression:

Water chestnuts are blossoming in the deep pond, oh!

My sweetie girl is going to marry, and I am not reconciled, oh!

My sweetie girl is going to marry and become a pair [with someone else], oh!

I in the face of this can do nothing but gasp, oh! ${ }^{39}$

菱角開花在深潭, 囉,

妹當要嫁兄唔甘，囉;

妹當嫁出成雙對, 囉,

兄當着只喘大氣，囉。

Zhong's taste for the genuineness of the love-themed Dan folksongs parallels the new literature proponents' appreciation of the authentic emotions shown in love songs (qingge 情歌) in "reaction to oppression by the Confucian moral order." 40

Zhong's scholarship on Dan folksongs belonged to folklore studies (minsuxue 民俗學) as an emerging disciplinary field in twentieth-century China. Inspired by the folklore movements in Japan and Europe and originating in Beida's folksong campaign, Republican Chinese folklore aimed to unveil the lives and voices of the folk, long ignored or repressed by the ruling elite, through folksongs and other folklore genres. ${ }^{41}$ For the Republican-era folklorists, "the folk" meant more than the rural peasantry and mountain-living people. Appreciating the minzu diversity of China, Dong Zuobin 董作賓, a leading folklore proponent, stated in 1927 that "our so-called folk [民間 minjian] was not restricted to the Han; all those minzu within China, such as the Miao, Yao, Dan [emphasis added], Luoluo 猓猓 etc. were the folk too." 42 For the first generation of the folklorists, not only the highland Southwest but also the translocal watery fringes inhabited by the Dan people were integral to the folkscape of China.

Zhong's interests in the Dan were not limited to their folksongs. While gathering local saltwater songs, in 1926 he conducted a brief survey on some 3,000 Dan people in a harbor adjacent to Shanwei 汕尾 city in Haifeng and published the results in a five-page report. In addition to quoting

\footnotetext{
${ }^{37}$ Zhong, 1927c.

${ }^{38}$ Zhong 1927a, p. 15.

${ }^{39}$ Zhong $1927 \mathrm{c}$.

${ }^{40}$ Hung 1985, p. 68.

${ }^{41}$ Gao 2019; Shi 2018.

${ }^{42}$ Dong 1927, p. 3.
} 
four locally circulated folksongs, Zhong discussed in the report the founding myths of Dan as a minzu and introduced various aspects of their lives and customs. ${ }^{43}$ Apart from the Dan, Zhong was interested in the folk customs of other minorities. Three months before completing his report on the Dan, he wrote another one on the mountain-dwelling Miao near Haifeng, whom, like the Dan, he regarded as an "uncivilized" minzu or "human species" (minzhong 民種) in Guangdong. ${ }^{44}$

Zhong worked in Guangzhou in 1927-1928 at Sun Yat-sen University, the center of the Chinese folklore movement in general and folklore scholarship on the Dan in particular in the late 1920s. ${ }^{45}$ Thanks to the efforts of Zhong and others, the Folklore Society was established in 1927 at the university's Institute of Philology and History. The institute housed its official organ, Folk Literature and Art (Minjian wenyi 民間文藝), and Folklore (Minsu 民俗), the latter two initially edited by Zhong. In the late 1920s these three journals were the major venues for publishing articles on the folklore of minority minzu, including the Dan. In total they had eight articles on the Dan, four of which constituted a special issue entitled “Dan People" (“Danhu zhuanhao" 蛋戶專號) in Folklore in 1929. In addition to folksongs, the articles examined the origin myths and historical legends about the Dan as well as their folk customs such as marriage and religious practice.

While most early scholarship on the Dan folklore focused on Guangdong, the Dan in Fujian also came under the folklorists' purview. The Folklore special issue included a short article on two ballads sung by the boat-dwelling Dan in Fuzhou and a photograph of entertainment boats in Zhangzhou 漳 州. They were both contributed by Xie Yunsheng 謝雲聲, a folklore amateur based in Xiamen 廈門. ${ }^{46}$ Shen Ji 沈䮑, probably a student of Fukien Christian University in Fuzhou, sketched the origin, distribution, and customs of the Dan as an "alien" (teshu 特殊) and weak provincial minzu in an article of the university's folklore journal. He proposed ways to "civilize" (kaihua 開化) the Dan such as promoting education and encouraging intermarriage with the Han. ${ }^{47}$

The nationalist motivation behind the folklore studies on the Dan was based on both the Han-centric national identity and regional identity of the authors. Chang-tai Hung has argued that for Republican folklorists, a "vital sense of national identity could be cultivated through a closer identification with the 'low' culture." 48 This identification was also predicated on their regional identity. Dan folklore scholarship evinces strong geographical orientation; folklore studies on the Dan in Guangdong and Fujian, as indicated above, were conducted by natives or residents of Guangdong and Fujian, respectively. In the first half of the twentieth century, scholars from Guangdong and elsewhere explored the local folklore and presented it as an integral part of their regional culture, which, they believed, played an important role in the development of a new national culture. ${ }^{49}$ The case of Zhong Jingwen is illustrative. A native of eastern Guangdong, Zhong regarded the folklore of the Dan as well as other minzu in Guangdong as indispensable part of the province's folklore as a whole. His regional identity drove his interests in the non-Han minzu folklore of Guangdong as an effort to build up the country's new national culture.

Overall, pre-1949 articles on the Dan folklore were mostly brief narrations lacking in-depth analysis, which is indeed one major deficiency of early Chinese folklore studies. It was hoped that folklore, a nascent academic field far from being independent, could complement other disciplines such as linguistics and sociology and serve as the basis of improving the folk's lives and customs. ${ }^{50}$ The scholarship on the Dan's folklore, however, was small in size and seldom cited in other disciplines, and only one writer of the Dan folk customs (i.e. Shen Ji) proposed means to improve their minzu status. The published folklore materials about the Dan mainly concerned their folksongs, which were chiefly

\footnotetext{
${ }^{43}$ Zhong 1926b.

${ }^{44}$ Zhong 1927b.

${ }^{45}$ Gao 2019, pp. 96-129.

${ }^{46}$ Xie 1929, p. 62.

${ }^{47}$ Shen 1933.

${ }^{48}$ Hung 1985, p. 17.

${ }^{49}$ Cheng 2006, pp. 213-41.

${ }^{50}$ Gao 2019, pp. 107, 118.
} 
treated as literary sources contributing to the new literature movement. All these limitations and shortcomings notwithstanding, the scholarship on the Dan folklore, from Zhong's folksong collecting efforts in Guangdong to Fujian folklorists' writings on the Dan as an "alien" minzu, helped establish the Dan as non-Han minzu folk on the eve of the nationality identification project in China in the 1950s.

\section{Ethnohistory and anthropology}

Another disciplinary focus of modern Dan scholarship is ethnohistory. With a long scholarly tradition, history developed into an academic discipline in China in the first decades of the twentieth century, when the rise of new historiography (xin shixue 新史學) shifted its focus from the political elite to people from all walks of life, including the "indigenous" minzu. In the rapidly emerging field of ethnology or "minzu studies" (minzuxue 民族學), scholars categorized the Han and non-Han and their branches, traced their origins and descendants, and examined their composition, interaction, and mixture, with specific attention to the non-Han people's assimilation into the Han in the past and present. Methodologically, early ethnohistorians were influenced by both Chinese historiographical traditions and Western social scientific theories and approaches. ${ }^{51}$

The pioneering historian of the Dan was Luo Xianglin, who examined their past and present as part of his book project on the Guangdong minzu. In what he planned to be the first chapter of the monograph (which never materialized), Luo outlined the ethnological composition of the province, tracing the origins and evolution of each of the classified $z u$ including the Dan. Immediately after writing this introduction, Luo completed in 1929 “The Dan People" (“Danjia” 蛋家), the pioneering essay that delved into the origins, historical evolution, and current status of the Dan minzu. ${ }^{52} \mathrm{He}$ also published an essay in 1934 on the Dan during the Tang dynasty (618-907) and another one in 1941 on the Dan's history and current situation. ${ }^{53}$

Luo's ethnohistorical studies on the Dan and Guangdong's minzu in general were based on his ethnic-regional identity as a Han in the province. He studied the ethnology of Guangdong in order to highlight their historical roles in China and the world. ${ }^{54}$ For him the Guangdong people were dominated by three branches of the Han minzu, including the Hakka (Kejia 客家). A native of a Hakka county in eastern Guangdong, he was a prominent scholar of the Hakka, whom he considered the "pure" Hanzu characterized by patriotism. For Luo, although the Hakka were racially and culturally superior to the Dan, they both belonged to Guangdong's minzu. The ethnological history of the Dan, who were illiterate and unable to report on their own social conditions, should be clarified to understand their contribution to China in the past and present. ${ }^{55}$

Luo's introduction to Guangdong's minzu and first essay on the Dan were published in Folklore. For him, folklore and ethnology were inseparable. He argued that folksongs and folktales were "remains" of the consciousness and customs of people in the remote past and thus these folk materials and their changes revealed the evolution of human activities in ancient history. ${ }^{56}$ Applying this theory, Luo employed folksongs of the Dan in Guangdong ethnohistorical studies. For example, he quoted folksongs from Zhong Jingwen's Dan ge to explain the Dan people's dialect and prove their linkage with the ancient southern Yuezu 越族. Like many contemporary historians, Luo treated folklore materials as excellent historical sources for studying the "primitive" minzu, who reflected ancient history. ${ }^{57}$

Despite his interest in folklore, Luo's scholarship on the Dan developed upon historical training. His history teachers at Tsinghua and Yenching Universities in Beijing included Gu Jiegang 顧頡剛,

\footnotetext{
${ }^{51}$ Moloughney and Zarrow 2011; Sang 2008, pp. 103-28; Wang 2001.

${ }^{52}$ Luo 1929a, p. 49; Luo 1929b; Luo 1929c, pp. 1-48.

${ }^{53}$ Luo 1934; Luo 1941.

${ }^{54}$ Luo 1929 c, pp. $39-44$.

${ }^{55}$ Cheng 2006, pp. 241-59; Luo 1928a, pp. 15-18; Luo 1933a, pp. 13-14, $248-72$.

${ }^{56}$ Luo 1928b, p. 35; Luo 1939.

${ }^{57}$ Luo 1940, p. 739; Luo 1941, p. 52; Sang 2008, pp. 116-18.
} 
Zhu Xizu 朱希祖, and Chen Yinke 陳寅恪, all prominent historians of the time who inherited the Qing-era evidential scholarship, adopted a philological approach, and advocated using various kinds of primary sources. ${ }^{58}$ In his ethnohistorical articles on the Dan, Luo quoted a wide range of written records including the official standard histories, gazetteers and geographical treatises, and the literati's miscellanies and anthologies. Adopting an evidential approach, Luo examined historical texts that mentioned the Dan and their antecedents, descendants, and related tribes to trace the Dan's origins and evolution as well as their relations with other ancient $z u$ or minzu. Luo's philological approach to the Dan history is reflected in his etymological and phonetic focus. He closely examined the ancient meanings and pronunciations of the character dan, its semantic and phonetic variants, and the associated ethnonyms.

Luo's basic argument about the Dan history is that the Dan descended from the southern Yuezu traceable to the Jin period, when they first appeared in textual records. First dwelling on land in the southwest and establishing the kingdom of Nanzhao 南詔 (738-902), the Dan were later forced by the Han to migrate to water, a view parallel to that of Liang Qichao, his Tsinghua teacher. Frequently citing Liang's writings on minzu and subscribing to his culturalist theory, Luo contended that by now the Dan and Han basically shared the same customs and language. ${ }^{59}$ In other words, Luo paradoxically argued for the large extent of the Dan's historical assimilation into the Han even though the Dan had still existed as a distinct minzu.

Luo did not limit source materials for Dan studies to ancient Chinese texts. He argued that folklore, geography, archaeology, and anthropology were all useful for developing Chinese ethnology. ${ }^{60}$ Among the imported social scientific disciplines, physical anthropology was particularly appealing. Luo listed in his notebook, in English, the "Instruments for the use of Physical Anthropological Survey" including anthropometer, spreading caliper, sliding compass, steel tape, and color scale. ${ }^{61}$ Luo's interests in physical anthropology were associated with his racially based belief in the importance of renzhong, or human species, in ethnology. He categorized Guangdong's people into the yellow, black, white, and unverified renzhong. Unlike the late-Qing intellectuals who used "minzu" and "renzhong" interchangeably, Luo differentiated between them. For him renzhong was one the four criteria for the formation of minzu, the other three being geography, language, and culture. Two factors determined renzhong, namely humans' blood and physical compositions. While Luo considered the Dan to be descendants of the Yuezu at a later stage of his ethnohistorical research, his original assumption was that the Dan belonged to an unverified renzhong. Doing blood test and physical measurements in the south, Luo believed, helped trace the origins and evolution of the Dan and clarify their position in Guangdong's ethnotaxonomy. ${ }^{62}$

Luo implemented his own racially informed anthropological ideas in his ethnographic research on the Dan. He represented Yenching University on a trip to Guangdong in 1932 to "measure and test human species" (ceyan renzhong 測驗人種) with Paul H. Stevenson, an American physician and anthropometrist of China's minorities. ${ }^{63}$ Before the trip Luo made an anthropometric chart divided into the "measurement" and "observation" sections. During his 4-month ceyan renzhong trip, he conducted research on the Dan in Guangzhou and northern Guangdong in March and April 1932. In Guangzhou, Luo measured some forty or fifty Dan people at a police station, entertainment boats, and a prison. He drew some tables and charts based on the measurement data. ${ }^{64}$ Apart from practicing anthropometry on land, Luo also went to boats and spoke with the Dan on board. He inquired about and observed various aspects of their lives such as their clothing and accessories, leisure and entertainment, and children's educational status. He visited a school in the city established for boat dwellers.

\footnotetext{
${ }^{58}$ Luo 1970; Luo 1971, p. 315; Luo 1977 [1943], p. 77.

${ }^{59}$ Luo 1929 b, p. 12.

${ }^{60}$ Luo 1929a, p. 51.

${ }^{61}$ Cheng 2008; Luo ca. 1932.

${ }^{62}$ Luo 1929b, pp. 2-3, 30; Luo 1933b, pp. 39-40.

${ }^{63}$ On the trip, see Cheng 2008.

${ }^{64}$ Luo 1932b; Luo 1966 [1932], pp. 203-06; Luo 1966 [1950], p. 62.
} 
After his Guangzhou research Luo made a trip to Qujiang 曲江, a northern Guangdong county where several rivers intersected. He conducted an in-depth interview with a man in his sixties living afloat near the county capital. ${ }^{65}$

During and after the ceyan renzhong trip, Luo made a series of research reports and travel notes, which constitute the earliest ethnography of the Dan. Luo's major finding was the Dan's mixture of blood, which in fact contradicted his presumption that they constituted a renzhong. Luo's explanation on this contradiction was that while the Dan and Han did not originate from the same zhong, the Dan often bought from orphanages the female children abandoned by the Han, who later married Dan males. That partly explained the "Hanization" (Hanhua 漢化) of the Dan and why the Guangzhou residents and Dan people shared some renzhong characteristics. ${ }^{66}$ Luo's struggle to explain his ethnographic (and also historical) finding that the Dan had been largely assimilated into the Han originated in his racial assumption of the Dan as a non-Han renzhong. His racialist ideas were both inherited from the Chinese past (as indicated in his reliance on imperial Chinese records of the Dan as a non-Han $z u$ in ethnohistorical research) and informed by the Western social scientific disciplines.

Not only racial thoughts, Luo's Dan ethnohistorical studies were also inseparable from his nationalist-patriotic beliefs. A Guomindang member since 1927 who took government and party positions under the Nationalist regime, he upheld the party's thoughts for strengthening China and solving its “national problems." ${ }^{67}$ Luo presented the "Dan-people problem" (Danmin wenti 蛋民問題) as a minzu issue that could be settled by exploring the Dan's past and present as the basis of measures to improve their lives and status. Contextualizing the need for studying the Dan within Sun Yat-sen's Three People's Principles (sanmin zhuyi 三民主義), Luo thought that the "national" (minzu) and "democratic" (minquan 民權) issues of the Dan had been resolved thanks to the Guomindang's call for the liberation of and equality between different minzu. Their livelihood (minsheng 民生) problem, however, had not yet been thoroughly addressed. Luo suggested improving the Dan's minsheng by developing coastal farmland and protecting fishery. ${ }^{68}$

Luo completed his last article on the Dan in 1940, when he was a professor in the Nationalist base in the Southwest during China's War of Resistance against Japan (1937-1945). He published it in 1941 in National Culture (Minzu wenhua 民族文化), a patriotic journal. Almost killed in a Japanese bomb attack, he argued that all the minzu in China and Southeast Asia, who shared the same origin, should unite against the Japanese. ${ }^{69}$ His strong anti-Japanese feelings informed his narrative of the Dan. Luo praised the "righteous revolutionary acts" (geming yiju 革命義舉) of the Dan against foreign rule during the early Qing. He also appreciated the donation by some Dan people to the national salvation movement after the 28 January Incident in 1932, affirming their anti-Japanese sentiments and membership in the Republic. Nevertheless, Luo conceded that some villainous riverine Dan had probably collaborated with the Japanese in the 1938 fall of Guangzhou. Their absence of educated leaders, Luo argued, would render it easy for the enemy to manipulate; if properly organized and trained, the Dan could defend the state given their talents such as bravery. ${ }^{70}$ Like other contemporaneous ethnologists, Luo hoped to mobilize the non-Han minorities - the Dan being one - to become a force serving the anti-Japanese cause.

The combination of Luo's regional identity and patriotism inspired his 1941 Dan article and other wartime writings on the ancient southern Yuezu or Baiyue 百越. In face of the Japanese invasion, Luo subscribed to the widespread notion of "Zhonghua minzu" and supported Chiang Kai-Shek to be their leader under the banners of "national survival" (minzu shengcun 民族生存) and "national rejuvenation" (minzu fuxing 民族復興). ${ }^{71}$ He considered the southern Baiyue a branch of the "Zhongxia

\footnotetext{
${ }^{65}$ Luo 1932a; Luo 1958, pp. 43-45.

${ }^{66}$ Luo 1966 [1932], p. 210.

${ }^{67}$ Cheng 2006, pp. 257-58; Lin 1992, pp. 1-2; Luo 1930, p. 42.

${ }^{68}$ Luo 1929b, p. 19; Luo 1941, pp. 56-59.

${ }^{69}$ Luo 1958, pp. 62-64.

${ }^{70}$ Luo 1941, pp. 57-59.

${ }^{71}$ Luo 1938, p. 5. On "national rejuvenation” in Republican China, see Huang 2018, pp. 286-320.
} 
system” (Zhongxia xitong 中夏系統) of the Zhonghua minzu, and the Dan, descending from the Baiyue, had already been incorporated into the Zhongxia system, psychologically speaking. Tracing the Dan thus revealed the historical evolution of the Zhonghua minzu, which, in turn, helped "the construction of the Southwest frontier" (Xi'nan bianjiang de jianshe 西南邊疆的建設). ${ }^{72}$ In other words, Luo, from a regional perspective, regarded the Dan as indispensable members of the Zhonghua minzu in the Southwest (which encompassed Guangdong) whose bonds with other minzu were traceable to the ancient past. Luo's incorporation of the Dan and other southern minorities into the Zhonghua minzu discourse exemplifies academic studies on China's non-Han people to achieve national unity in face of the Japanese invasion. ${ }^{73}$

\section{Conclusion}

Late Qing-Republican scholarship on the Dan as a $z u$, minzu, zhongzu, and renzhong characterizes the early development of humanities and social sciences in modern China. ${ }^{74}$ First, it involved a variety of emerging disciplinary fields. Zhong Jingwen's efforts on the Dan folklore lay at the intersection of the new literature movement and folklore studies, whereas Luo Xianglin, ethnohistorian of the Dan, subscribed to folklore and physical anthropology. Behind the different disciplinary approaches is the shifting of focus from the upper-level elite to the lower strata of society including the non-Han minorities. Materials used to study the ordinary people involved a wide range of sources, textual and non-textual alike. Republican-era intellectuals of the Dan not only examined written historical records but also gathered, organized, and published the orally transmitted popular literature such as folksongs, other folkloric materials, and ethnographic and anthropometric data. These studies were grounded on the writers' nationalist concerns, their Han and regional identities, and, above all, the belief of the Dan as a $z$, zhongzu, minzu, and/or renzhong, a racially informed notion whose origin was traceable to imperial Chinese records centuries ago and whose popularity to the last decade of the Qing. Considered as a whole, the modern intellectual writings examined in this article established the Dan as a littoral non-Han minzu on the eve of the nationality classification project in the PRC.

The intellectual explorations of the Dan before 1949 had a profound impact on the state policies for and scholarship on the Dan afterward. The late Qing-Republican discussions on the Dan as a $z u$, minzu, zhongzu, and renzhong informed the premise of the three state-initiated social surveys on the Dan in Guangdong in 1952-1953 that the Dan were a shaoshu minzu. One investigation report, for example, concluded that "historically they [the Dan] are certainly shaoshu minzu."75 Similarly, in Fujian, the provincial teams investigating the Dan in 1952-1953 also presumed that they constituted a shaoshu minzu. Han Zhenhua 韓振華, a Xiamen University professor, viewed from a Han perspective and considered the Dan “our brother minzu” (women de xiongdi minzu 我們的兄弟民族) and clamored for preference policies to support them. ${ }^{76}$ Luo Xianglin's trip to clarify the ethnotaxonomic position of the Dan and his call for solving their minzu problem as a way to construct a strong multiminzu state, in particular, predated the PRC's goal of its nationality identification of the Dan. The ideal of improving the Dan's livelihoods in much of the pre-1949 scholarship continued in the official and academic circles throughout the second half of the twentieth century. Into the late twentieth and early twenty-first centuries, folklore and ethnohistory have still been two mainstreams of Mainland Dan studies. ${ }^{77}$ As late as the 1980s, a Guangdong scholar still conducted anthropometric research on the Dan in the Pearl River Delta to examine whether they were Han or non-Han minzu, following Luo Xianglin's steps fifty years earlier. ${ }^{78}$

\footnotetext{
${ }^{72}$ Luo 1941, pp. 55-56; Luo 1943.

${ }^{73}$ For similar scholarly efforts, see Leibold 2007.

${ }^{74}$ On humanities and social sciences in China before 1949, see Sang 2001.

${ }^{75}$ Guangdongsheng minzuyanjiusuo 2001 [1953], p. 64.

${ }^{76}$ Fan 2012, pp. 934-37; Huang 2019, pp. 190-93.

${ }^{77}$ See, for example, Lin, Wu, and Long 2014; Zhang 1991.

${ }^{78}$ Huang 1990.
} 
Why were the Dan, having been identified as a distinct tribal group since the fourth century and a non-Han minzu since the last years of the Qing, finally classified as Han but not a shaoshu minzu in 1955 during the nationality identification campaign? As scholars have demonstrated, the countrywide minzu identification varied in different regions, and its outcome was a function of the participation and interaction of the central authorities, local cadres and investigators, the elite and other members of the classified groups, and their neighbors. ${ }^{79}$ From the nationality inquiries into the Dan, the central officials and investigators in Guangdong and Fujian concluded that their language and customs were similar to those of the Han, and that the Dan did not evince an "ethnic consciousness" and regard themselves as a distinct minority group. For the PRC authorities and minzu shibie participants, the Dan, though historically a minzu, had been largely assimilated into the Han even though their mode of residence (i.e. living on water) still remained largely different from the Han majority. This "Hanization" of the Dan was also noticed by many Republican-era scholars, who, however, still presumed that the Dan constituted a non-Han minzu based on a combination of their traditional Chinese and Western racialist ideas, self-identification as Han, regional identity, and vision of China as a multiminzu state. The history of the Dan from being non-Han to Han, thus, demonstrates the equal importance of the intellectuals' nationalist orientations, academic thoughts, and ethnic-regional backgrounds in the making of the geoethnic landscape in modern China.

Acknowledgements. James C. Scott, Han Xiaorong, and John M. Carroll provided useful feedback on the earlier versions of this article.

Conflict of interest. The author(s) declare none.

\section{References}

Cheng, Meibao 程美寶 (Ching May-bo) (2006). Diyu wenhua yu guojia rentong: Wan-Qing yilai “Guangdong wenhua” guan de xingcheng 地域文化與國家認同: 晚清以來「廣東文化」觀的形成 (“Local Culture and National Identity: The Formation of the Notion of 'Guangdong Culture' since the Late Qing”). Beijing: Sanlian shudian.

Cheng, Meibao (Ching May-bo) (2008). “Luo Xianglin zaonian renzhongxue yu minzuxue de linian yu shijian” 羅香林早年 人種學與民族學的理念與實踐 (“The Idea and Practice of Luo Xianglin's Early Anthropology and Ethnology”). Zhongshan daxue xuebao (shehuikexueban) 中山大學學報 (社會科學版) (Journal of Sun-Yat-sen University [Social Sciences Section]) 48:6, pp. 82-93.

Ching, May-bo (2007). “Classifying Peoples: Ethnic Politics in Late Qing Native-Place Textbooks and Gazetteers.” In The Politics of Historical Production in Late Qing and Republican China, eds. Robert Culp and Hon Tze-ki, pp. 55-77. Leiden: Brill.

Chow, Tse-tsung (1960). The May Fourth Movement: Intellectual Revolution in Modern China. Cambridge, MA: Harvard University Press.

Culp, Robert (2007). Articulating Citizenship: Civic Education and Student Politics in Southeastern China, 1912-1940. Cambridge, MA: Harvard University Asia Center.

Dennis, Joseph R. (2015). Writing, Publishing, and Reading Local Gazetteers in Imperial China, 1100-1700. Cambridge, MA: Harvard University Asia Center.

Dikötter, Frank (2015). The Discourse of Race in Modern China. Oxford: Oxford University Press.

Dong, Zuobin 董作賓 (1927). “Wei Minjian wenyi jinggao duzhe” 為民間文㙯敬告讀者 (“Respectful Admonition to the Readers of Folk Literature and Art”). Minjian wenyi 民間文藝 (Folk Literature and Art) 1, pp. 1-5.

Fan, Ke (2012). "Ethnic Configuration and State-Making: A Fujian Case." Modern Asian Studies 46:4, pp. 919-45.

Faure, David (2007). Emperor and Ancestor: State and Lineage in South China. Stanford, CA: Stanford University Press.

Gao, Jie (2019). Saving the Nation Through Culture: The Folklore Movement in Republican China. Vancouver: UBC Press.

Gladney, Dru C. (1991). Muslim Chinese: Ethnic Nationalism in the People's Republic. Cambridge, MA: Council on East Asian Studies, Harvard University.

Guangdongsheng minzuyanjiusuo 廣東省民族研究所 ed. (2001 [1953]). Guangdong Danmin shehui diaocha 廣東蛋民社 會調查 (“Social Surveys on the Guangdong Dan people”). Guangzhou: Zhongshan daxue chubanshe.

Hao, Yulin 郝玉麟 (1792 [1730]). Guangdong tongzhi 廣東通志 (“Guangdong Gazetteer”). Beijing: Qinding siku quanshu, vol. 57.

Harrell, Stevan ed. (1995). Cultural Encounters on China's Ethnic Frontiers. Seattle: University of Washington Press.

\footnotetext{
${ }^{79}$ Yang 2008.
} 
Harrison, Henrietta (2001). China: Inventing the Nation. London: Arnold.

Hostetler, Laura (2001). Qing Colonial Enterprise: Ethnography and Cartography in Early Modern China. Chicago, IL: University of Chicago Press.

Huang, Foyi 黃佛頣 (2015 [1906]). “Guangdong xiangtushi jiaokeshu.” 廣東鄉土史教科書 (“Guangdong Native-place History Textbook”). In Guangzhou dadian 廣州大典 (“Guangzhou Encyclopedia”), eds. Chen Jianhua 陳建華 and Cao Chunliang 曹淳亮, vol. 338, pp. 185-220. Guangzhou: Guangzhou chubanshe.

Huang, Guangxue 黃光學 (1995). Zhongguo de minzu shibie 中國的民族識別 (“China's Nationality Identification”). Beijing: Minzu chubanshe.

Huang, Xiangchun 黄向春 (2008). “Cong Danmin yanjiu kan Zhongguo minzushi yu zuqun yanjiu de bainian tansuo” 從疍 民研究看中國民族史與族群研究的百年探索 (“A Centennial Exploration of Ethnohistory and Ethnic Studies in China: The Case of Dan Studies”). Guangxi minzu yanjiu 廣西民族研究 (Guangxi Ethnology) 94, pp. 55-65.

Huang, Xiangchun (2016). “Going beyond Pariah Status: The Boat People of Fuzhou in the People's Republic.” In The Fisher Folk of Late Imperial and Modern China: An Historical Anthropology of Boat-and-Shed Living, eds. He Xi and David Faure, pp. 142-58. Abingdon, UK: Routledge.

Huang, Xiangchun (2019). “Shenfen, zhixu, yu guojia: 20 shiji 50 niandai Minjiang xiayou diqu de 'shuishangren' yu guojia jian'gou” 身份、秩序與國家—-20 世紀 50 年代閩江下游地區的“水上人”與國家建構 (“Identity, Order, and the State: The 'Waterborne People' in the Lower Min River Region and State Construction in the 1950s"). Kaifang shidai 開放時代 (Open Era) 6: pp. 182-200.

Huang, Xingtao 黃興濤 (2018). Chongsu Zhonghua: jindai Zhongguo “Zhonghua minzu” guannian yanjiu 重塑中華 : 近代 中國「中華民族」觀念研究 (“Remolding Chinese: A Study of the Concept of 'Zhonghua Minzu' in Modern China”). Beijing: Beijing shifan daxue chubanshe.

Huang, Xinmei 黃新美 (1990). Zhujiangkou shuishangjumin (Danjia) de yanjiu 珠江口水上居民（疍家）的研究 (“Study of Waterborne Residents (Dan People) in the Pearl River Mouth"). Guangzhou: Zhongshan daxue chubanshe.

Hung, Chang-tai (1985). Going to the People: Chinese Intellectuals and Folk Literature, 1918-1937. Cambridge, MA: Council on East Asian Studies, Harvard University.

Leibold, James (2007). Reconfiguring Chinese Nationalism: How the Qing Frontier and Its Indigenes Became Chinese. New York: Palgrave Macmillan.

Liang, Qichao 梁啟超 (1905). “Lishishang Zhongguo minzu zhi guancha” 歷史上中國民族之觀察 (“Observation on China's Historical Minzu”). Xinmin congbao 新民叢報 (New Citizen Journal) 3:17, pp. 43-62.

Lin, Tianwei 林天蔚 (1992). “Luo Xianglin zhuanlüe” 羅香林傳略 (“Brief Biography of Luo Xianglin”). In Luo Xianglin jiaoshou jinian lunwenji 羅香林敎授紀念論文集 (“Festschrift in Honor of Professor Luo Xianglin”), ed. Zhuhai wenshi yanjiusuo xuehui 珠海文史研究所學會, vol. 1, pp. 1-7. Taipei: Xinwenfeng.

Lin, Youneng 林有能, Wu Zhiliang 吳志良, and Long Jiaji 龍家玘 eds. (2014). Danmin wenhua yanjiu (er): dier jie Danmin wenhua xueshu yantaohui lunwenji 疍民文化研究（二） - 一第二屆疍民文化學術研討會論文集 (“Cultural Studies on the Dan People (II): Collection of Essays of the Second Academic Conference on the Dan People's Culture"). Hong Kong: Xianggang chubanshe.

Liu, Shipei 劉師培 (1934-1936 [1903]). Rangshu 攘書 (“Book of Expulsion”).

Luo, Xianglin 羅香林 (1928a). “Du Zhong zhu Minjian wenyi conghua” 讀鍾著“民間文藝叢話” ("Review of Folk Literature by Zhong Jingwen”). Minsu 民俗 (Folklore) 33, pp. 5-25.

Luo, Xianglin (1928b). Yuedong zhi feng 粵東之風 (“Guangdong Folksongs”). Shanghai: Beixin shuju.

Luo, Xianglin (1929a). “Benkan tongxun” 本刊通訊 (“Correspondence”). Minsu 民俗 (Folklore) 63, pp. 49-53.

Luo, Xianglin (1929b). “Danjia” 蛋家 (“Dan People”). Minsu 民俗 (Folklore) 76, pp. 1-32.

Luo, Xianglin (1929c). “Guangdong minzu gailun” 廣東民族概論 (“Introduction to Guangdong's Minzu”). Minsu 民俗 (Folklore) 63, pp. 1-48.

Luo, Xianglin (1930). “Woguo minzu qingxiang de yipie” 我國民族傾向之一瞥 (“Review of A Glance at the Trend of Our Country's Minzu”). Xinmin banyuekan 新民半月刊 (New Citizen Bimonthly) 16, p. 42.

Luo, Xianglin (1932a). “Danhu tanwen ji” 蛋戶探問記 (“Records on Inquiring about the Dan”). In “Yitang zhaji” 乙堂札 記, vol. 1. Lo Hsiang Lin Collection, Fung Ping Shan Library, University of Hong Kong.

Luo, Xianglin (1932b). “Hua'nan zhuzuxi diaocha yu ceyan jilüe” 華南諸族系調查與測驗紀略 (“Summary of the Investigations and Examinations on $Z u$ in South China"). In "Yitang zhaji” 乙堂札記, vol. 11. Lo Hsiang Lin Collection, Fung Ping Shan Library, University of Hong Kong.

Luo, Xianglin (ca. 1932). “Zaji” 雜記 (“Miscellaneous Notes”). In “Yitang zhaji” 乙堂札記, vol. 8. Lo Hsiang Lin Collection, Fung Ping Shan Library, University of Hong Kong.

Luo, Xianglin (1933a). Kejia yanjiu daolun 客家研究導論 (“Introduction to Hakka Studies”). Guangzhou: Xingning xishan shucang.

Luo, Xianglin (1933b). “Minzu yu minzu de yanjiu” 民族與民族的研究 (“Minzu and Minzu Studies”). Wen-shixue yanjiusuo yuekan 文史學研究所月刊 (Monthly of the Institute of Literature and History) 1:1, pp. 39-40.

Luo, Xianglin (1934). “Tangdai Danzu kao shangpian” 唐代蛋族考上篇 (“Study of the Tang-era Danzu [I]”). Wen-shixue yanjiusuo yuekan 文史學研究所月刊 (Monthly of the Institute of Literature and History) 2:3-4, pp. 13-56. 
Luo, Xianglin (1938). “Wei minzu shengcun er yonghu lingxiu” 為民族生存而擁護領袖 (“Support the Leader for National Survival”). Minyi 民意 (Public Opinion) 26, p. 5.

Luo, Xianglin (1939). Preface to Minjian shishuo 民間世說 (“Collection of Folktales”) by Lin Peilu 林培盧. Shanghai: Ertong shuju.

Luo, Xianglin (1940). “Gudai Yuezu fangyan kao.”古代越族方言放 (“Study of the Ancient Yuezu’s Dialect”). In Guangdong wenwu 廣東文物 (“Guangdong Cultural Relics”), ed. Zhongguo wenhua xiejinhui 中國文化協進會, pp. 732-40. Hong Kong: Guangdong wenwu zhanlanhui.

Luo, Xianglin (1941). “Danmin yuanliu yu wenhua” 蛋民源流與文化 (“Dan People’s Origin, Evolution, and Culture”). Minzu wenhua 民族文化 (National Culture) 2, pp. 48-60.

Luo, Xianglin (1943). Zhongxia xitong zhong de Baiyue 中夏系統中的百越 (“The Baiyue in the Zhongxia System”). Chongqing: Duli chubanshe.

Luo, Xianglin (1958). Dadi shengyou ji 大地勝遊記 (“A Travelogue”). Hong Kong: Yazhou chubanshe.

Luo, Xianglin (1966 [1932]). “Zai Yue ceyan renzhong jilüe” 在粵測驗人種紀略 (“Summary of Measuring and Testing Human Species in Guangdong”). In Minsuxue luncong 民俗學論叢 (“Anthology of Folklore”), pp. 203-10. Taipei: Wenxing shudian.

Luo, Xianglin (1966 [1950]). “Zhongguoren duiyu yan bi toufa dengdeng de kanfa” 中國人對於眼鼻頭髮等等的看法 (“Chinese Views on Eyes, Noses, Hair etc.”). In Minsuxue luncong 民俗學論叢 (“Anthology of Folklore”), pp. 59-66. Taipei: Wenxing shudian.

Luo, Xianglin (1970). “Huiyi Chen Yinke shi” 回憶陳寅恪師 (“Commemorating Teacher Chen Yinke”). Zhuanji wenxue 傳 記文學 (Biography Literature) 17:4, pp. 13-20.

Luo, Xianglin (1971). “Zhu Xizu.” 朱希祖 (“Zhu Xizu”). In Zhongguo wenhua zonghe yanjiu 中國文化綜合研究 (“Integrated Chinese Cultural Studies”), ed. Zhonghua xueshuyuan 中華學術院, pp. 307-36. Taipei: Zhonghua xueshuyuan.

Luo, Xianglin (1977 [1943]). “Sanshiwu sui zizhu” 三十五歲自述 (“Autobiography Written at Age Thirty-five”). In Yitang wencun xubian 乙堂文存續編 (“Anthology of Luo Xianglin [II]”). Hong Kong: Zhongguo xueshe.

Moloughney, Brian and Peter Zarrow (2011). "Making History Modern: The Transformation of Chinese Historiography, 1895-1937." In Transforming History: The Making of a Modern Academic Discipline in Twentieth-Century China, pp. 1-45. Hong Kong: Chinese University Press.

Mullaney, Thomas S. (2011). Coming to Terms with the Nation: Ethnic Classification in Modern China. Berkeley: University of California Press.

Mullaney, Thomas S., James Leibold, Stéphane Gros, and Eric Vanden Bussche eds. (2012) Critical Han Studies: The History, Representation, and Identity of China's Majority. Berkeley: University of California Press.

Qu, Dajun 屈大均 (1985 [1700]). Guangdong xinyu 廣東新語 (“New Comments on Guangdong”). 2 vols. Beijing: Zhonghua shuju.

Sang, Bing 桑兵 (2001). Wan-Qing Minguo de guoxue yanjiu 晚清民國的國學研究 (“Study of Late Qing-Republican China's Learning”). Shanghai: Shanghai guji chubanshe.

Sang, Bing (2008). Wan-Qing Minguo de xueren yu xueshu 晚清民國的學人與學術 (“Late Qing-Republican Scholars and Studies"). Beijing: Zhonghua shuju.

Sato, Yoshifumi (2016). "The Recent History of the Fishing Households of the Nine Surnames, a Survey from the Counties of Jiande and Tonglu, Zhejiang Province." In The Fisher Folk of Late Imperial and Modern China: An Historical Anthropology of Boat-and-Shed Living, eds. He Xi and David Faure, pp. 173-82. Abingdon: Routledge.

Schneider, Julia C. (2017). Nation and Ethnicity: Chinese Discourses on History, Historiography, and Nationalism (1900s1920s). Leiden: Brill.

Shen, Ji 沈焂 (1933). “Fujiansheng nei jizhong teshu minzu de yanjiu” 福建省內幾種特殊民族的研究 (“Study of Several Alien Minzu in Fujian Province”). Fujian wenhua 福建文化 (Fujian Culture) 2:11, pp. 1-9.

Shi, Aidong 施愛東 (2018). Zhongguo minsuxue de guchui yu jingying 中國民俗學的鼓吹與經營 (“The Development of Modern Chinese Folklore"). Taipei: Xiuwei zixun keji.

Siu, Helen F. and Liu Zhiwei (2006). "Lineage, Market, Pirate, and Dan: Ethnicity in the Pearl River Delta of South China." In Empire at the Margins: Culture, Ethnicity, and Frontier in Early Modern China, eds. Pamela Kyle Crossley, Helen F. Siu, and Donald S. Sutton, pp. 285-310. Berkeley: University of California Press.

Szonyi, Michael (2002). Practicing Kinship: Lineage and Descent in Late Imperial China. Stanford, CA: Stanford University Press.

Teng, Emma Jinhua (2004). Taiwan's Imagined Geography: Chinese Colonial Travel Writings and Pictures, $1683-1895$. Cambridge, MA: Harvard University Asia Center.

Tong, Zhenzao 童振藻 (1931). “Qianjiang Jiuxing yuhu kao” 錢江九姓漁戶㪀 (“Study of the Nine-surname Fishing Households along the Qiantang River”). Lingnan xuebao 嶺南學報 (Lingnan University Journal) 2:2, pp. 4-50.

Wang, Chuan 王傳 (2018). Minguo shiqi Guangdong xueren yu Zhongguo Xi'nan yanjiu 民國時期廣東學人與中國西南研 究 (“Scholars and China’s Southwest Studies in Republican-era Guangdong). Shanghai: Shanghai guji chubanshe. 
Wang, Q. Edward (2001). Inventing China Through History: The May Fourth Approach to Historiography. New York: SUNY Press.

Wang, Zhengang 王振剛 (2013). Minguo xueren Xi'nan bianjiang wenti yanjiu 民國學人西南邊疆問題研究 (“Republican-era Studies on the Southwestern Frontier Problems”). Beijing: Renmin chubanshe.

Xie, Yunsheng 謝雲聲 (1929). “Fuzhou Danhu de gediao” 福州蛋戶的歌調 (“Songs of the Fuzhou Dan People”). Minsu 民 俗 (Folklore) 76, pp. 33-36.

Yang, Bin (2008). "Central State, Local Governments, Ethnic Groups and the Minzu Identification in Yunnan (1950s1980s).” Modern Asian Studies 43:3, pp. 741-75.

Yang, Fang-yen (1999a). “Nation, People, Anarchy: Liu Shih-p'ei and the Crisis of Order in Modern China.” Ph.D. dissertation, University of Wisconsin-Madison.

Yang, Zhe 楊哲 (1999b). Fengyu shijixing: Zhong Jingwen zhuan 風雨世紀行——鍾敬文傳 (“Biography of Zhong Jingwen"). Shanghai: Huadong shifan daxue chubanshe.

Zarrow, Peter (2006). "Liang Qichao and the Conceptualization of 'Race' in Late Qing China.” Zhongyang yanjiuyuan Jindaishi yanjiusuo jikan 中央研究院近代史研究所集刊 (Bulletin of the Institute of Modern History, Academia Sinica) 52, pp. 113-64.

Zarrow, Peter (2012). After Empire: The Conceptual Transformation of the Chinese State, 1885-1924. Stanford, CA: Stanford University Press.

Zarrow, Peter (2015). Educating China: Knowledge, Society, and Textbooks in a Modernizing World, 1902-1937. Cambridge: Cambridge University Press.

Zhan, Jian'gu 詹堅固 (2004). “Jianguohou dang he zhengfu jiejue Guangdong Danmin wenti shulun” 建國後黨和政府解決 廣東疍民問題述論 (“The Party and Government's Solutions to the Dan-People Problem after 1949”). Dangdai Zhongguoshi yanjiu 當代中國史研究 (Contemporary Chinese Historical Studies) 11.6: pp. 91-101.

Zhan, Jian'gu 詹堅固 (2009). “Lun Yongzhengdi kaihuo Guangdong Danhu jianji” 論雍正帝開豁廣東蛋民賤籍 (“Emperor Yongzheng's Abolition of the Mean Household of Dan in Guangdong). Xueshu yanjiu 學術研究 (Academic Studies) 11, pp. 117-22.

Zhang, Shouqi 張壽祺 (1991). Danjiaren 蛋家人 (“Dan People”). Hong Kong: Zhonghua shuju.

Zhong, Jingwen 鍾敬文 (1926a). “Danhu lian'ge” 蛋戶戀歌 (“Dan People’s Love Songs”). Liming 黎明 (Dawn) 31, pp. 84-85.

Zhong, Jingwen (1926b). “Shanwei Xin'gang Danmin diaocha” 汕尾新港蛋民調查 (“Survey on the Dan People in Xingang, Shanwei”). Beijing daxue yanjiusuo guoxuemen zhoukan 北京大學研究所國學門周刊 (Weekly of the National Learning Institute, Peking University) 2:22, pp. 228-32.

Zhong, Jingwen (1927a). Dan ge 蛋歌 (“Dan Folksongs”). Shanghai: Kaiming shudian.

Zhong, Jingwen (1927b). “Huiyang Shezaishan Miaomin de diaocha”惠陽㞰仔山苗民的調查 (“Survey on the Miao People in Shezai Mountain, Huiyang”). Zhongshan daxue yuyan-lishixue yanjiusuo zhoukan 中山大學語言歷史學研究所周刊 (Weekly of the Institute of Philology and History, Sun Yat-sen University) 6, pp. 142-44.

Zhong, Jingwen (1927c). “Zhongguo Danmin wenxue yiluan” 中國蛋民文學一變 (“A Glimpse of the Dan-people Literature in China”). In Zhongguo wenxue yanjiu 中國文學研究 (“Chinese Literary Studies”), ed. Zheng Zhenduo 鄭振鐸, vol. 2. Shanghai: Shangwu yinshuguan.

Zhong, Jingwen (1928). “Guangdong Fanzaishan de Yaomin” 廣東軬仔山的猺民 (Yao People in Fanzai Mountain, Guangdong”). Dongfang zazhi 東方雜誌 (Eastern Miscellany) 25:6, pp. 97-99.

Zhong, Jingwen (1997). Xueni hongzhao: Zhong Jingwen zishu 雪泥鴻爪一一鍾敬文自述 (“Autobiography of Zhong Jingwen"). Taiyuan: Shanxi renmin chubanshe.

Zhong, Jingwen (1998 [1989]). “Wusi shiqi minsu wenhuaxue de xingqi”五四時期民俗文化學的興起 (“The Rise of Folk Culturology during the May-Fourth Period”). In Zhong Jingwen minsuxue lunji 鍾敬文民俗學論集 (“Collection of Zhong Jingwen's Essays in Folklore”), ed. Tu Shi 涂石, pp. 292-340. Shanghai: Shanghai wenyi chubanshe.

Zhu, Jingxing 朱景星 and Zheng Zugeng 鄭祖庚 (2001 [1906]). Houguanxian xiangtuzhi 侯官縣鄉土志 (“Houguan County Native-place Gazetteer"). Fuzhou: Haifeng chubanshe.

Cite this article: Luk Gary Chi-hung (2023). The making of a littoral minzu: The Dan in late Qing-Republican intellectual writings. International Journal of Asian Studies 20, 1-17. https://doi.org/10.1017/S1479591421000401 